\title{
ISIS Terror on detik.com Online Media in Indonesia
}

\author{
Ribut Priadi $^{1,3}$, Syukur Kholil2, Iskandar Zulkarnain ${ }^{3}$ \\ ${ }^{1}$ Ph.D Student in State Islamic University of North Sumatera (UINSU), Medan, Indonesia \\ ${ }^{2}$ Lecturer in State Islamic University of North Sumatera, Medan, Indonesia \\ ${ }^{3}$ Lecturer in Faculty of Social and Political Science, University of North Sumatera (USU), Indonesia \\ email: 1 ributpriadi@gmail.com,${ }^{3}$ iskandar.zulkarnain@usu.ac.id
}

\begin{abstract}
Bomb explosions carried out by the ISIS network in Indonesia attracted the attention of the mass media, both local, national and international, including detik.com and republika.co.id. In covering the events, each media had a different perspective so that gave birth to the tendency in the news. Framing reporting aims to make the audience also have a similar tendency to the media read. The purpose of this study is: To find out the tendency of reporting on ISIS by detik.com and its implications for the reader's perception of the Islamic state. This study uses a qualitative approach with a type of descriptive research that aims to explain the implications of detik.com framing related to ISIS terrorism news in Indonesia, especially regarding audience perceptions about the Islamic Caliph. Media framing was carried out through the analysis of Zondang Pan and Kosicki. For framing effects the reception theory is used. The speakers were activists of Islamic Student Organizations, IMM, KAMMI, HMI, HIMMAH and PMII. The results showed that detik.com's readers' perception of the Islamic State was a positive concept, but it did not have to be realized in a formal or forced form, especially in Indonesia. Detik.com readers also view the concept of Islamic sharia as something positive, but not made in formal form through statutory regulations. In detik.com news, it is more likely to be neutral by submitting field facts and opinion facts in the news without relating to matters related to Islam.
\end{abstract}

Keyword: terrorist news, media framing, reader perception, online media, islamic state

\section{Introduction}

The presence of the Islamic State of Iraq and Sham (ISIS) has caused shock in the world. ISIS, which first proclaimed itself as a state on 9 April 2013, attracted international attention because its members came from various countries, including Indonesia. Hundreds and even thousands of young people from Indonesia are thought to have joined ISIS.

ISIS is heavily engaged in recruitment using various methods, through kidnapping or propaganda through social media. ISIS has Al Itisam, a propaganda media that is quite effective in recruiting sympathizers from various parts of the world. Even to attract ISIS sympathy deliberately displays information in English or other foreign languages as presented by $\mathrm{Al}$ Hayat Media Center under the control of Al Itisam. Promotion for recruitment is not only using videos, which first appeared between 2 June and 4 June 2014, but also pamphlets and magazines. Counterterrorism analyst Patrick Pole said the recruitment media was made 
professionally with competent English speakers without grammatical and spelling errors, including in Arabic.

ISIS also utilizes social media to attract sympathizers in various parts of the world, including in Indonesia. Observers of terrorism acts Al Chaidar claim ISIS has succeeded in pledging around 2 million people in Indonesia. Although there was no exact data, he claimed that the information he obtained was directly from his colleague who had joined ISIS in Iraq. While the National Counter Terrorism Agency (BNPT) noted that there were 30 Indonesians who had left for Iraq.

The loss of 16 Indonesian citizens during a visit to Turkey also gave rise to speculation, they joined ISIS. As quoted from BBC Indonesia, some of the 16 Indonesians reportedly missing in Turkey and alleged to have joined the Islamic State or ISIS militant group in Syria are members of the terrorism network in Indonesia, according to a former Indonesian security official.

For the Indonesian government, the presence of ISIS members in the country is feared to give birth to a new terrorist group. As stated by the Head of the National Counterterrorism Agency Ansyaad Mbai, ISIS Indonesia will become a new terrorist group. He considered that Indonesians who went to Iraq and joined ISIS would return as terrorists. In other words, the potential for the birth of terrorist acts that are identical to bombings, suicide bombings and criminal acts such as robbery is a necessity. Indonesia itself is one of the countries targeted by acts of terrorism. Starting from the October 12, 2002 bomb blast in Legian Bali which killed at least 203 people died and hundreds were injured and disabled. A high-powered bomb explosion also occurred on August 5, 2003 at the JW Marriott Hotel. Subsequently, on September 9, 2004 a bomb exploded in front of the Australian Embassy in Jakarta. Medan City residents were also shocked by the robbery of CIMB Niaga on Jalan Aksara, Medan on August 18, 2010, which was later known to be masterminded by terrorist groups.

\section{Review of Literature}

\subsection{Agenda Setting Theory}

Issues around terrorism become one of the interesting things for the media. Likewise with the presence of ISIS in the post-invasion of the United States to Iraq which resulted in the overthrow of Saddam Hussein from power. ISIS, which later attracted the attention of the international community, including Indonesia, always had a place in the news both in print, electronic and online media. The news about ISIS and the actions of its followers that are synonymous with acts of terrorism that are so prominent is not a coincidence. Media news that was made so prominent by being placed on the main page of newspapers or special coverage of acts of terrorism allegedly carried out by ISIS followers in Indonesia could be called the agenda setting.

Agenda setting theory that has existed since the beginning of the 20th century is a communication theory that is still relevant today. For the people, the problems with ISIS that are so complex will be very difficult to understand. Journalists and editors simplify it through written news. People may think that ISIS is not something to think about, but the media is successful in telling people to think about it and make it a matter of concern. Quoting Cohen 1963, perhaps the press was not very successful in telling people what they thought, but it was usually successful in telling people what they should think about. 
Setting Agenda can be said to be the most powerful theory, in the science of communication. The advantages of this theory are the result of its concise but broad description, quality, basis of the studies of his theory and its relationship to other theories in communication. The main idea behind the agenda setting theory is that issues that are considered important media will influence what will later be considered important by the community. It is this transfer of important perceptions of media to the public which later became known as the setting agenda in the study of communication theory. In other words, the media tells us what to think about.

Agenda setting theory starts with an assumption that the mass media filter the news, articles or writings that will be broadcast. Media workers such as editors, journalists, determine which should be highlighted or hidden, which events are worth covering or what issues are considered important for public knowledge or discourse. Developing events or issues are given certain weight by placing them on the newspaper page or broadcast repeatedly on television.

\subsection{Framing}

The idea of Framing was first raised by Baterson. Frame is initially interpreted as a conceptual structure that organizes political views, policies and discourses and provides standard categories to appreciate reality.

There are several definitions put forward by experts on framing in Eriyanto, each of which differs in its emphasis and understanding, but there is still a major point of reference for the definition, namely:

a. According to Robert Etman framing is a selection process in various aspects of reality so that certain aspects of the event are more prominent than other aspects. He also stated that information in a typical context so that certain get greater allocation than the other side.

b. According to Todd Gitlin, the strategy of how reality or the world is formed and simplified in such a way as to be displayed to the public. Events are displayed in the news to make it stand out and attract the attention of readers. It is done by selection, repetition, emphasis and presentation of certain aspects of reality.

c. According to David Snow and Robert Benford, giving meaning to interpreted events from relevant conditions. Frame organizes belief systems and is manifested in certain keywords, such as clauses, certain images, sources of information and certain sentences.

d. According to Zhongdan and Pan Konsicki as construction and processing news. The cognition device used in coding information, interpreting events related to the routine and news formation conventions.

This concept was also given by Erving Goffman in 1974 which presupposes the frame as behavioral pieces that guide individuals in reading reality. Humans actively classify, organize and interpret their life experiences to be more meaningful. Understanding schemes symbolized by frames cause humans to be able to find, think about, identify and provide signs as events or information. Frame offers interpretation of various social realities that take place every day.

In the illustration, Gamson (2001) identified three domain studies from the framing approach: (1) the origin and use of frames in the construction of messages, (2) the examination of certain frames in messages, and (3) the interaction of audiences with these messages. In communication research, both the setting and framing agenda both include specific content about media messages and the effects of the content on the public. And, as we can see, two approaches simultaneously are almost indistinguishable in showing questions about media content and the effects of media content. However, the framing approach and agenda setting 
differ largely in terms of the source and use of frames in media messages, with much more emphasis on this field in framing research.

\subsection{Framing Analysis, A Text Analysis Method}

In the realm of communication studies, framing analysis represents a tradition that promotes a multidisciplinary approach or perspective to analyze communication phenomena or activities. Framing analysis is used to dissect ways of media ideology when constructing facts. This analysis examines selection strategies, prominence, and linking facts into the news so that they are more meaningful, more interesting, more meaningful or more memorable to lead audience interpretation according to their perspective.

The word salience is defined as making information more attentive, meaningful and memorable. An increase in prominence increases the probability of the recipient to better understand information, see the meaning more sharply and then process it and store it in memory. The information part of the text can be made more prominent by placing it or repeating or associating it with familiar cultural symbols.

The basic idea of framing analysis is how a media text is viewed as an organized system, which shows advocacy for certain ideas and provides a means for the audience to process the text. According to Erving Goffman in Zein, humans actively classify, organize and interpret their life experiences to be more meaningful. Understanding schemes symbolized by frames cause humans to be able to find, think about, identify and provide signs as events or information.

In other words, framing is an approach to knowing how the perspective or perspective of journalists when selecting issues and writing news. The perspective or perspective finally determines what facts will be taken, which parts are highlighted and eliminated, and where to take the news.

\subsection{Framing Analysis Model Pan and Kosicki}

This study uses a framing analysis model from Zhondang Pan and Gerald M. Kosicki. This model was put forward by Zhondang Pan and Gerald M. Kosicki in his writing Framing Analysis: An Approach to News Discourse (1993). Pan and Kosicki define framing as a process of making a message more prominent, placing information more than others, so that the audience is more focused on the message.

In the Pan and Kosicki framing model, framing devices are divided into four major structures namely syntactic structure, script structure, thematic structure and rhetorical structure. The four structures are a series that can show the framing of a medium. The tendency or inclination of journalists in understanding an event can be observed from the four structures.

\subsection{Media Language as Construction of Reality}

In doing reality construction, the mass media uses language as the main tool in telling reality. Language is a conceptualization and narrative tool. Once the importance of language, there is no news, stories or knowledge without language. Peter L. Berger and Thomas Luckman in his book The Social Construction of Reality, A Treatise in the Sociology of Knowledge (1967) explained that the process of constructing reality begins when a constructor does objectivity towards a belief that is to do a perception of an object. Furthermore, the results of the meaning through the perception process are internalized into a constructor. In this stage conceptualization of an object that is perceived is carried out. The final step is to externalize 
the outcome of the internal reflection process through statements. The statement making tool is nothing but words or concepts or languages.

Furthermore, the use of certain languages will determine certain narrative (and meaning) formats. Indeed, if we look closely, all the contents of the mass media, both print and electronic media must use language. News texts that are present as a result of the construction of journalists are displayed using language so that they can be read and seen by the public. In this case Agus Sudibyo explained that the existence of language other than as a tool to expose reality, but also can determine the picture of a reality that is the media reality that will then appear in the minds of audiences.

The use of a particular language may be implicated in the form of construction of reality and meaning that will contain. The choice of words and the way in which they present a reality help determine the construction structure of reality and the meaning that emerges from it. From this perspective, even language is not only able to reflect reality, but at the same time can create reality. as shown in the picture below:

\section{Figure. 1: The relationship among language, reality and culture}

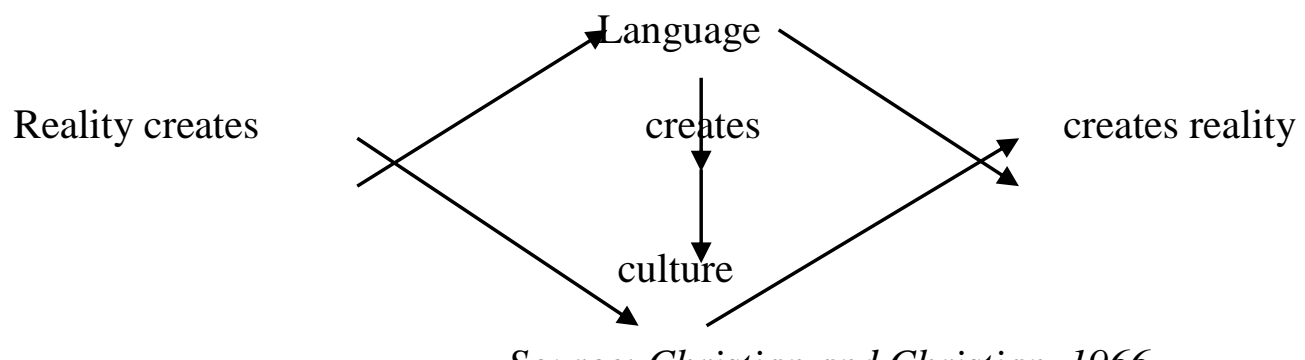

Source: Christian and Christian, 1966

\section{Research Methodology}

This study uses a qualitative approach that is descriptive. In this study, framing analysis was used to determine the tendency of news by detik.com. In framing analysis, news texts are seen to consist of various symbols arranged through symbolic devices to be constructed in the memory of audiences. In other words, there are no objective messages or stimuli, whereas news texts are seen as a set of codes that require interpretation. Framing analysis also does not see the news text as a message that just exists, but is formed through certain structures and formations, involving the production and consumption of a text. Validity is seen from how the text stores codes that can be interpreted in a certain way by the researcher.

Furthermore, to find out the framing effect, reception analysis method was used. Reception analysis refers to a comparison between framing analysis and audience perception. In this study the audience is seen as part of the interpretive communitive which is always active in perceiving the message and producing meaning, not just being a passive individual who only accepts the meaning produced by the mass media.

Operationally, in this study researchers attempted to understand the construction of ISIS reporting by detik.com and so that researchers could provide a description of the different effects on individual perceptions, because the same text might be different in different individuals. 


\section{Discussion}

\subsection{Syntax}

Detik.com initiated the news of the Thamrin bombing by presenting short news or journalism known as flash news. This brief news has an incomplete news scheme, but still with an inverted pyramid structure. This short news writing method is quite common in online media because competition can be accessed more quickly by the community so that it can get attention while attracting as many readers. Flash news is commonly raised when major events occur. Editorial news portals usually prioritize what elements in the news scheme. Detik.com then uploads advanced news which is also incomplete so that it is more visible as a cut of events. The news displayed by detik.com in its entirety about the sequence of the Thamrin bomb was in the form of a chronology of events by taking the title, "The Chronology of ISIS Terror in Thamrin". From syntactic analysis, the title raised is one of the themes raised from the many themes that surfaced in the Thamrin bomb or also called the Sarinah bomb which took place on Thursday (1/14) morning. The news about the Thamrin Bomb, was quite intriguing because of the alleged involvement of ISIS which was one of the terrorism movements based in Iraq and Syria. In the title displayed detik.com explicitly reveals the link between the bombing in Jalan Thamrin Jakarta and the Islamic state movement ISIS.

Only in the lead and the content section, detik.com did not explain the evidence of ISIS involvement in the Jakarta bombings. The word ISIS only appears in the headline. In the chronology of events, detik.com took the title, "ISIS Chronology of Terror in Thamrin", the lead that appeared was usually an explanation related to the theme of the title. But in the news the lead did not mention ISIS. The following leads are displayed:

Seven people were declared dead in a series of terror attacks in the MH Thamrin area, Central Jakarta. Of the 7 people, 5 of them were perpetrators and the other 2 victims were Canadian and Indonesian citizens. The police said that within 15 minutes the conditions on the field were successfully controlled.

In the news body written by detik.com, there was also no explanation about the evidence of a connection between the events and the ISIS movement. Discourse about victims and sequences of events is more dominantly expressed through sources in this case Metro Jaya Regional Police Chief Inspector General Tito Karnavian.

In a statement quoted by detik.com also did not mention the relationship between the perpetrators of the Thamrin bombing and the ISIS movement. In the body of the news written about the sequence of events starting with a suicide bombing on Starbuck Cofee to the success of the police securing the location of the incident.

The news text was closed with the process of the crime scene and the location of the incident, precisely at Jalan Thamrin reopened. The closing news seemed flat and without emphasis so that the discourse about ISIS displayed in the title seemed to be released. Chronological news that discusses about ISIS as the perpetrator of the bombing, although it is not explained in the news, but was revealed in the previous news. For readers who want to take part in detik.com's news, they can understand the emergence of ISIS discourse, but for readers who do not follow the details of the news displayed regarding the Thamrin bombing incident, it will be difficult to understand the chronological news because it is not connected between the title, lead and body or news content. This means that to understand the ISIS discourse behind the bomb blast on the chronological news posted by detik.com, readers must follow the previous news. 
Previously detik.com had displayed the news that took the statement of the Head of the Jakarta Metro Police Inspector General Tito Karnavian who pointed directly at ISIS behind the terrorist bombing at Thamrin. Detik.com uploaded the headline of the Metro Police Chief: "Actor of Terror in Thamrin ISIS Group".

In the written news lead, Jakarta Metropolitan Regional Police Chief Inspector General Tito Karnavian ensured that terrorists in the Cakrawala and Jalan Thamrin buildings in Central Jakarta were connected to the Islamic State of Iraq and Syria (ISIS) group based in Raqqa. From syntactic analysis, the themes displayed are dominant about ISIS and the movement to build organizational influence throughout the world.

Another theme is about the background of the terrorist acts in Thamrin as a form of competition for influence to become the leader of ISIS Southeast Asia. This theme is an excuse to strengthen the existence of ISIS as a mastermind in a terrorist act on Jalan Thamrin.

Detik.com also revealed the theme of an Indonesian ISIS figure as the mastermind behind the suicide bombing. Bahrum Naim's figure as an Indonesian ISIS figure was revealed by the author to convince readers that suicide bombing acts as a terrorist act which is related to moving ISIS in Indonesia. The emergence of the name Bahrum Naim as well as reinforcing the reason detik.com will be the existence of the ISIS movement in Indonesia so that people are alert. It's just that detik.com only digs up information from one news source. The issue of ISIS involvement and the existence of Bahrum Naim's figure revealed by detik.com came from the Metro Police's statement. Detik.com in this news does not attempt to find a comparison source that can confirm the direct relationship between the perpetrators of the explosion with the ISIS network or Bahrum Naim who claimed to want to build influence as ISIS leaders in Southeast Asia.

The themes revealed in each other's news were mutually reinforcing, as well as being a chronological news base so detik.com was vulgarly uploaded the title "ISIS Terror Chronology in Thamrin". Through the themes displayed by detik.com trying to lead readers' opinions to tend to link the news of ISIS terror in Thamrin as part of the ISIS movement to disrupt security while building influence in Indonesia.

While in the previous news entitled, "Cursed Bom Thamrin, MUI Asks for Fast Motion and the People Keep Calm" based on syntactic analysis, detik.com uploaded it before the headline "Terrorists in the ISIS Group Thamrin" and "ISIS Terror Chronology in Thamrin".

Based on the title and material of the news uploaded by detik.com, it appears how the author tries to lead the reader to come to a conclusion about the perpetrators behind the acts of terrorism in Thamrin. Before posting the chronology news, detik.com had uploaded MUI comments related to the Thamrin bomb, then took the Kapolri statement which intentionally emphasized the side of ISIS involvement so that in chronological news, readers were expected to understand what was happening and who was behind the perpetrators. The MUI statement related to the pressure to expose the perpetrators was quickly answered through detik.com news.

Through detik.com's news about the serially uploaded Thamrin bomb, it has led readers to give an appreciation to the National Police that can quickly overcome the situation and rapid response in responding to demands and public pressure to immediately expose terrorists.

The effort of detik.com to lead readers to a conclusion about the terrorist bombers of Thamrin was seen in serial news loading. Framing of detik.com's news began with pressure from community leaders in this case represented by the MUI, followed by police statements and chronological news that immediately called ISIS in the news title. 
Based on the syntactic analysis of the news entitled, "Cursed Bom Thamrin, MUI Asks the Apparatus to Move Fast and the Community Still Calm" there are a number of themes raised and seen in the title, lead and news body elements. The theme raised in the title is one of several themes raised in the news of the Thamrin bomb or also called the Sarinah bomb which took place on Thursday (1/14) morning.

News of the MUI statement uploaded by detik.com to address the actions of the Thamrin Bombers, is quite interesting because it concerns the alleged involvement of ISIS organizations which very clearly carry the name of Islam. ISIS which is one of the terrorism movements based in Iraq and Syria is considered not to represent Islamic attitudes and thoughts. The MUI as the highest organization that oversees Indonesian Islamic scholars is very interested in providing information so that people do not misunderstand the information about ISIS in circulation. But detik.com in the headline that quoted the MUI did not review the ISIS movement in the view of the MUI scholars, but put the ulama organization only as a representative of religious figures who were anxious about acts of terrorism. In the title displayed detik.com expressly condemns terrorism and asks the authorities to immediately arrest the perpetrator.

The lead shown by detik.com supports the theme in the title. Lead explains more clearly about the news title. However, there are three themes summarized in the news lead, namely condemning acts of terror, demanding that the apparatus immediately arrest the perpetrators and try and appeal for calm. In the lead, the MUI did not review in detail about Islam. The statement of the ISIS movement which justifies violence contrary to Islamic teachings is only written in the final paragraph of the news content. But even then it was not specifically mentioned, just mentioned not to be associated with any religion, not just Islam.

Themes that appear in the news content support the theme of titles and leads. The themes in the news content also support each other. In addition to explaining the theme revealed in the lead, the content of the news also contains a theme not to link the contents of terror with certain religions and sympathy to the families of the victims. Based on the themes displayed in the news, detik.com tends to avoid discussing acts of terrorism with Islam. detik.com tries to be neutral by not reviewing ISIS which carries the name of Islam in terms of religion even though it makes the leaders of the MUI as resource persons. Detik.com tends to invite readers to understand the actions of bombings and shootings from the side of terrorism crime.

\subsection{Script}

Based on the analysis through the script structure, you can see how detik.com tells the story of the news elements. detik.com in its title puts forward the element of who and what in this case the quote from the Jakarta Police Chief's statement which was used as the title, "Actors of Terror in the ISIS Group Thamrin". The title displayed by detik.com is one way to attract the attention of the reader while making it easier for the reader to immediately understand the events that occur.

Based on the script analysis, after the title followed by leads arranged with elements of who, what, where and when. While the elements of why and how appear in the body of the news so that all the elements of the news $5 \mathrm{w}+1 \mathrm{H}$ have been completed. But from all the news elements included in the news structure, especially for the element (who), the news source is only single and is not equipped with comparative information or comparison sources so that the reader does not have room to understand more comprehensively about the Thamrin bomb explosion. Impressed detik.com tends to direct readers to one opinion. 
The impression that detik.com directs readers to one view of terrorists in Thamrin is sympathizers or members of ISIS, it is clear in the structure analysis of news scripts that are uploaded next. Based on the structure of the news script entitled, "The Chronology of ISIS Terror in Thamrin" can be seen how detik.com tells events by compiling news elements starting from what, who and where. The way to tell like this will make the reader more quickly find out who is behind the Thamrin Bomb blast. It's just that because the ISIS discourse in the title there is no further explanation in the lead or in the news body, it leaves the question in the reader's mind. The title of the chronology news which directly referred to ISIS as the mastermind behind the Thamrin bombing suggests a belief in the information about the involvement of the organization labeled as terrorists as the brain behind the terrorism act.

On the body of the news, in addition to placing when and where, detik.com also raises who (the source in the news) and how (how the order of the bomb blasts). But detik.com did not explore the elements of who (the perpetrators) so that the news that was written was only one-sided, namely from the police. In the chronology news, it also appears unilaterally, namely from the police without comparison sources. This makes the how on the news body seem very flat because it comes from one source without comparison from the community as eyewitnesses or observers or other parties to provide confirmation of ISIS involvement in the explosion. The ISIS discourse that surfaced in the news seemed flat because there was no background explanation. The element of the reason that is the reason for ISIS's claims behind the Thamrin bomb terror has no explanation.

Detik.com in chronological news seems to be trying to lead readers to see cases of suicide bombing in the region masterminded by ISIS, even though it only shows in the title without explanation in the lead or in the news body. The news displayed by detik.com by describing in complete and systematic terms the elements of $5 \mathrm{~W}+1 \mathrm{H}$ explained a lot about the victims and the success of the police in overcoming the Thamrin bomb terrorism. Another issue, through script elements, is less explored by detik.com so that readers do not comprehensively understand the real scene of events.

The news " ISIS's Terror Chronology in Thamrin " is actually still the previous news series, " Terrorists in the ISIS Thamrin Group " and "Cursed Bom Thamrin, MUI Requests the Movement's Fast and People Keep Calm". It can be understood if in the chronology news directly calls ISIS as a terrorist. Based on the analysis through the structure of the script, it can be seen how detik.com tells the events by compiling news elements starting from the statement of the MUI figure, then the Kapolda claim and chronology.

Detik.com in its title emphasizes the elements of who and what is good in the chronological news and the statement of the Regional Police Chief and the statement of the MUI scholars. On the news of the quotation from the Jakarta Police Chief's statement which was used as the title, "Actors of Terror in the ISIS Group Thamrin". The title displayed by detik.com is one way to attract the attention of the reader while making it easier for the reader to immediately understand the events that occur.

Based on the script analysis, after the title followed by leads arranged with elements of who, what, where and when. While the elements of why and how appear in the body of the news so that all the $5 \mathrm{~W}+1 \mathrm{H}$ news elements have been completed. However, from all the news elements included in the news structure, especially for the element (who), the news source is only single and not equipped with comparative information or comparison sources so that the reader does not have room to understand more comprehensively about the Thamrin bombing incident. Impressed detik.com tends to direct readers to one opinion. 


\subsection{Thematic}

From the thematic structure, there are 3 major themes in the news text namely, ISIS discourse which is displayed vulgarly in the title, even without further explanation. The next theme was the sequence of events, the number of victims and the success of the police in overcoming the bomb blast which was followed by a series of shootings by the perpetrators.

The news theme displayed by detik.com which directly referred to ISIS as the perpetrator in the Thamrin bombing was actually quite interesting, besides the chronology of the events and successes of the police who were described as not taking long to deal with acts of terrorism. ISIS revealed in the title is actually a theme that is considered most important by detik.com so that it is placed directly on the title.

However, this theme is not supported by details that explain ISIS involvement. This theme actually leads readers to blame terrorist acts that have caused lives to the ISIS movement. Unfortunately this theme was not explored enough by showing details of the involvement of suicide bombers and shooting with ISIS networks based in Syria and Iraq.

However, the explanation of the large number of victims in the Thamrin bomb blast that was displayed in the news lead, can be interpreted that what the perpetrators did in this case ISIS members or sympathizers were so sadistic that the community needed to provide support to resolve similar cases. The large number of victims displayed in the opening chronology news lead also gave the impression, the magnitude of the loss of lives due to crimes committed by the ISIS terrorist movement in the name of Islam.

Another theme raised in the chronological news is the sequence of events so that people understand the details of the suicide bombings and a series of shootings that have caused a number of casualties. Next is the theme of the ability of the police to quickly overcome terrorist acts carried out by ISIS so that people do not need to feel too worried about their security and safety.

In presenting the news "ISIS Chronology of Terror in Thamrin" detik.com used information on the previous news, namely "Terrorists in the ISIS Thamrin Group" and "Cursed Bom Thamrin, MUI Asked the Rapid Movement and the Community to Keep Calm". Based on thematic analysis, news "The perpetrators of terror in the ISIS Thamrin Group, support the news theme" ISIS Chronology of Terror in Thamrin ".

\subsection{Rhetorical}

The rhetorical structure of detik.com as a strategy for framing is through a photo of the Jakarta Police Chief, Major General of Police Tito Karnavian who stood on the podium giving a statement accompanied by the Coordinating Minister of Politics and Security, Luhut Binsar Panjaitan and the TNI Commander, Gen. Gatot Numantio, word and label selection strategy certain labels. The title of detik.com which deliberately directly mentioned the suicide bombing and ISIS shooting was an attempt to attract the attention of readers.

Detik.com deliberately presents a photo of the main official in charge of national security matters namely Menkopolhukam, the TNI Commander who accompanies the Metro Jaya Regional Police Chief so that readers can more quickly grasp the issue that is trying to convey. The photo loading also shows detik.com wants to lead readers to be sure of the government's seriousness in overcoming security issues, especially related to ISIS terrorism in Indonesia.

In terms of labels, detik.com places figures or figures of officials responsible for national security through uploaded photos and ISIS labels to strengthen the issues raised. Only the ISIS label revealed in the title does not get sharpened. 
The framing strategy conducted by detik.com shows little effort to appear objectively and professionally in placing facts. Seen from the speakers who only came from the police. The effort, detik.com tried to make some of the facts stand out through rhetorical elements that reinforced the message that the link between ISIS behind the Thamrin bomb terrorist act seemed less than optimal because of the limited facts from resource persons who were also limited.

\section{Conclusions}

The bombing incident in Thamrin was an event that drew the attention of the Indonesian people, even internationally. The terrorism action associated with ISIS is also the focus of the news on detik.com. The existence of ISIS influence in Indonesia is interesting because previously the base of the movement of organizations included in this list of terrorists was in Iraq and Syria. The idea of the Islamic Caliphate which was carried by ISIS was quite capable of attracting the sympathy of some Muslims, not least in Indonesia through the Daulah Jamaah Ansharut. The existence of ISIS's influence in Indonesia in the terrorist bombings made detik.com made special coverage to report developments from various sides and perspectives by presenting field facts, as well as opinion facts through resource persons. The tendency of detik.com to report on bomb explosions is known through the framing analysis of Zongdang Pan and Gerald M Kosicki. The instrument used to see the tendency of the news is syntactic, script, thematic and rhetorical structure. The news trend of detik.com emerged because the media had their own perspective or meaning in seeing the events in this case the bomb detonation terrorist action in Thamrin. The tendency of reporting is inseparable from the interests of the media or media owners regarding the ideology or politics of the media economy. To see the effect of the tendency of reporting was done using the reception theory. This theory is based on the view that the audience or audience is active and each has its own perspective in interpreting the text displayed by the mass media. In this context, research was conducted to see the similarity of perception or attitude to audeience with the framing carried out by the media in relation to the reporting of ISIS terrorism in Indonesia during the bomb explosion in Thamrin. The existence of ISIS itself cannot be separated from the idea of khilafah Islamiyah and the application of Islamic sharia.

\section{References}

Amiruddin, M. Hasbi. Konsep Negara Islam"dalam Fazlur Rahman. Yogyakarta. UII Press, 2000

Anugerah, Dadan. Modul Metode Penelitian Komunikasi. Universitas Mercu Buana.2016

Armando, Nina M (et al). Ensikopledi Islam, Jakarta. Ichtiar Baru Vam Hoeve, 2005

Azka, M Najib, Hegemoni Tentara. Yogyakarta. ISAI, 1994

Badara Aris, Dr, M Hum. Analisis Wacana, Teori, Metode dan Penerapannya Pada Wacana Media, Jakarta. Pranadamedia Group, 2012

Baran, Stanley J, Dennis K Davis. Teori Dasar Komunikasi Masa. Jakarta. Salemba Humanika, 2009

Bimo Nugroho, Eriyanto dan Frans Surdiasis. Politik Media Mengemas Berita. Jakarta. ISAI, 1999 
Birowo, M Antonius (ed). Metode Penelitian Komunikasi; Teori dan Aplikasi. Jakarta. Gitanyali, 2004

Bruhn Jensen, Klaus A. Handbook of Qualitative Methodologies for Mass Communication Research. London. Routledge. 1999

Burhan, Bungin HM, Prof, Dr, S Sos, MSi. Konstruksi Sosial Media Massa, Jakarta. Prenada Media Group, 2011

Chaidar, Al. " 2 Juta WNI Disebut Sudah Dibaiat ISIS" dalam Tempo.co. 20014

Creswell, John W. Research Desaign, Oendekatan Kualitatif dan Mixed, Ter. Ahmad Fawaid, Yogyakarta, Pustaka Pelajar.2010

Eadie, William F. 21st Century Communication A Reference Handbook. Volume I \& 2. San Diego State University, 2009

Eriyanto, Analisis Wacana: Pengantar Analisis Teks Media. Yogyakarta. LKIS,2001 LKIS, 2002

Fiske, John. Pengantar Ilmu Komunikasi, Diterjemahkan, Hapsari Dwiningtiyas, Jakarta, Raja Grafindo, 2012

Fuad, Zakki. Negara Islam atau Negara Nasional (Pemikiran Fundamentalis vs Liberal). Kediri. Jenggala Pustaka Utama, 2007

Habsari, Twediana Budi. Jurnal Aspikom. Vol. 1.2013

Hanson, Elizabeth C. "Framing The World News: The Times of India In Changing Times. Political Communication". Vol.12. 1996

Haj, Abu Abdul Fattah Ali Ben dan Muhammad Iqbal. Negara Ideal Menurut Islam (Kajian Teori Khilafah dalam Sistem Pemerintahan Modern. Jakarta. Ladang Pustaka \& Intimedia, 2001

Hanafi, Ahmad A. Hafizar. "Tata Negara, Jurnal Falasifa”. Vol 1. 2010

Hefni Harjani. Dr, LC, MA. Komunikasi Islam, Jakarta. Prenadamedia Group, 2015

Herdiansyah Haris, Msi. Wawancara, Observasi, dan Focus Groups Sebagai Instrumen Penggalian data Kualitatif, Jakarta, Rajagrafindo Persada, 2013

Ida Rachmah. Metode Penelitian, Studi Media dan Kajian Budaya, Jakarta, Prenada, 2014

Krisdinanto Nanang. "Anomali dan Teori Hirarki Pengaruh terhadap Isi Media”, Jurnal KOMUNIKATIF Volume 3, 2014

Kusumaningrat, Hikmat, Purnama. Jurnalistik, Teori dan Praktik. Bandung. Remaja Rosdakarya,2007

Leksono, Sugeng Puji. Metode Penelitian Komunikasi Kualitatif. Malang. Intrans Publishing.2015

Ma'arif, Ahmad Syafi'i. Islam dan Politik: Teori Belah Bambu (Masa Demokrasi Terpimpin. Jakarta. Gema Insani Press. 1996

Mbai, Ansyaad. Terkait "Jaringan Teroris", 16 WNI Diduga Ke Suriah" dalam BBC Indonesia.2015

M Romli, Syamsul Asep. Jurnalistik Online, Panduan Praktis Mengelola Media Online, Bandung, Nuansa Cendikia.2012

McQuail, Denis. Teori Komunikasi Massa; Suatu Pengandar. Edisi Kedua. Jakarta. Erlangga, 1987

Nasrullah Rulli, Dr, MSi, Teori dan Riset Media Siber, Jakarta. Pranadamedia Group, 2014 ..Media Sosial, Perspektif Komunikasi, Budaya, dan Sosioteknologi, Bandung, Simbiosa Rekatama Media, 2015 
Norman, Denzin K dan Lincoln S.Yvoonna. Handbook Of Qualitative Reserach. Yogyakarta. Pustaka Pelajar, 2009

Norris, Pippa. "The Restless Search Light: Network News Framing of The Post - Cold War World". Dalam Political Communication". Vol. 12. 1996

Novia, Dyah Ratna Meta Novia. "MUI: Muslim Sengaja Ditakut-takuti”. Dalam Republika,2015

Paloma M, Margaret. Sosiologi Kontemporer. Jakarta. PT Raja Grafindo Persada, 2000

Pulungan, J. Suyuthi. Prinsip-Prinsip Pemerintahan dalam Piagam Madinah Ditinjau Dari Pandangan Al-Qur'an. Jakarta. Rajawali Press, 1996

Quails, Mc Quail. Teori Komunikasi Massa. Jakarta. Salemba Humanika.2001

Syamsul, Asep, Romli, M. Jjurnalistik Online, Panduan Praktis Mengelola Media Online, Bandung. Nuansa Cendikia, 2012

Sobur, Alex. Analisis Teks Media. Bandung. Remaja Rosda Karya,2012

Ensiklopedia Komunikasi. Bandung. Simbiosa Rekatama Media,2014

Scheufele, D.A dan D. "Tweksbury. Framing Agenda Setting, and Priming: The Evolution of Three Media Effects Models. Journal of Communication.Vol.57, 2007

Shoemaker, Pamela J and Reese, Stephen D. Mediating the Message. Theories on influences on Mass Media Content. New York.Longman, 1991

Sumardiria AS Haris. Jurnalistik Indonesia, Menulis Berita dan Feature, Panduan Praktis Jurnalis Profesional, Simbiosa Rekatama Media, Bandung.2011

Sudibyo Agus. Citra Bung Karno: Analisis Berita Pers Orde Baru. Yogyakarta. LKIS,1999

Sudibyo Agus, Ibnu hamad, Muhammad Qodari. Kabar-kabar Kebencian; Prasangka Agama di Media Massa. Jakarta. ISAI,2001

Sutopo, H.B. Pengantar Penelitian Kualitatif. Surakarta. Universitas Sebelas Maret Press, 2002

Tashakori Abbas, Teddlie Charles, Handbook Of Mixed Methods In Social \& Behavioral Research, Terj. Dryatno. Jakarta, Pustaka Pelajar,2010

Taufik, Tata M. Etika Komunikasi Islam. Bandung. Pustaka Setia,2012

Tejomukti, Ratna Ageng. "Mengenal Isis". Dalam Republika, 2015

Toriquddin, H. Moh. Relasi Agama dan Negara (Dalam Pandangan Intelektual Muslim Kontemporer. Malang. UIN Malang Press, 2009

Walgito, Bimo. Pengantar Psikologi Umum. Yogyakarta. Yogyakarta Andi, 2010

Zen, Fathurin, NU Politik: Analisis Wacana Media. Yogyakarta. LKIS, 2004

\section{Internet}

http://e-journal.uajy.ac.id/2341/3/2KOM02726.pdf accessed on $15^{\text {th }}$ August 2018 on 04.42 p.m

https://id.wikipedia.org/wiki/DetikCom accessed on $15^{\text {th }}$ August 2018 on 10.08 a.m

https://id.wikipedia.org/wiki/Republika_(surat_kabar) accessed on $15^{\text {th }}$ August 2018 on 07.42 p.m

https://m.tempo.co/read/news/2014/12/28/078631345/jejak-aktivitas-isis-di-indonesia/2 https://nasional.republika.co.id/berita/nasional/hukum/18/05/14/p8psp1318-dari-manamunculnya-jad-yang-dilabeli-teroris

https://news.detik.com/berita/d-3118250/seorang-polisi-tewas-akibat-ledakan-di-pos-polisisarinah 
https://news.detik.com/berita/d-3118679/bom-di-thamrin-kepala-bin-sangat-mungkinpelakunya-dari-isis

https://news.detik.com/berita/d-3118790/kronologi-teror-isis-di-Thamrin accessed on $10^{\text {th }}$ October 2017 on 11.38 a.m

https://sinaukomunikasi.wordpress.com/2011/10/22/efek-framing-pemberitaan-televisitentang-unjuk-rasa-duglas-m-mcleod-dan-benjamin-h-detenber/ accessed on $6^{\text {th }}$ January 2016 on 10.24 a.m

http://sona-adiansah.blogspot.co.id/2013/06/efek-framing.html accessed on $6^{\text {th }}$ Januari 2015 on 10.26 p.m

http://www.dahlandahi.com/2013/08/jumlah-visitor-detikcom-kompas-vivanews.html accessed on $20^{\text {th }}$ September 2015 on 11.19 a.m

http://www.detik.com/dapur/redaksi accessed on $15^{\text {th }}$ August 2018 on 05.13 p.m

http://www.ibnukatsironline.com/2015/10/tafsir-surat-al-hujurat-ayat-12.html accessed on $26^{\text {th }}$ April 2017 on 10.00 a.m

http://www.ibnukatsironline.com/2015/09/tafsir-surat-al-ahzab-ayat-70-71.html accessed on $26^{\text {th }}$ April 2017 on 10.00 p.m

https://www.maxmanroe.com/budiona-darsono.html accessed on $14^{\text {th }}$ August 2018 on 09.30 p.m

https://www.republika.co.id/berita/internasional/timur-tengah/15/12/31/o06vvx377-ini-awalmula-pembentukan-isis accessed on $23^{\text {th }}$ September 2018

https://www.republika.co.id/berita/nasional/umum/16/01/14/o0xrv8365-kronologi-ledakansarinah-versi-polri accessed on $18^{\text {th }}$ October 2017 on 10.45 a.m

https://www.republika.co.id/berita/nasional/umum/16/01/14/o0xqdj359-mui-pelaku-bomsarinah-jauh-dari-nilai-keagamaan accessed on $18^{\text {th }}$ October 2017 on 11.01 a.m

https://www.viva.co.id/indepth/sorot/726604-peta-gerakan-isis-di-indonesia accessed on $18^{\text {th }}$ april 2018 